Creative commons User License: CC BY-NC-ND

Abstracted by: EBSCOhost, Electronic Journals Service (EJS),

Google Scholar, Directory of Open Access Journals (DOAJ),

Journal Seek, Scientific Commons,

Food and Agricultural Organization (FAO), CABI and Scopus
Journal of Agricultural Extension

Vol. 21 (3) October, 2017

ISSN(e): 24086851; ISSN(Print); 1119944X

http://journal.aesonnigeria.org

http://www.ajol.info/index.php/jae

Email: editorinchief@aesonnigeria.org

\title{
Effect of Privatisation of Agricultural Extension Services on Productivity of Fadama III Beneficiaries in Oyo State, Nigeria
}

https://dx.doi.org/10.4314/jae.v21i3.15

\section{Adegbemi, Samson Adegebo,}

Department of Agricultural Extension and Rural Development, University of Ibadan gbemigebo@gmail.com; +2348038565132

\section{Akinbile L. Abiodun}

Department of Agricultural Extension and Rural Development, University of Ibadan lakinbile@yahoo.com; +2348023250454

\section{Olutegbe Nathaniel Siji}

Department of Agricultural Extension and Rural Development, University of Ibadan siji004u@yahoo.com; +2347032077856

\section{Abstract}

This study examined effect of privatisation of agricultural advisory services of Fadama III project on farmers' productivity in Oyo state, Nigeria. Multi-stage sampling procedure was adopted in selecting 146 and 144 beneficiaries and non-beneficiaries respectively. Frequency, percentage, means, PPMC and t-test were used to analyse data. Most (52.7\%) of the beneficiaries had tertiary education, while $33.6 \%$ of the non-beneficiaries possessed secondary education, with respective average ages of 48.32 and 49.68. About 53\% of beneficiaries accessed credit through Fadama Users Group, while $53.4 \%$ of nonbeneficiaries accessed credit through commercial banks. Most of the beneficiaries obtained information on advisory services from friends (91.0\%) and extension agents (89.6\%), compared to non-beneficiaries from radio (95.2\%) and group meetings (81.5\%). Fadama III beneficiaries had higher level of access to advisory services than nonbeneficiaries. Production of poultry meat $(r=0.389, p<0.05)$ and eggs $(r=0.322, p<0.05)$ were significantly influenced by beneficiaries' access to advisory services. Level of access to advisory services was significantly higher $(t=1.651, p=0.045)$ for beneficiaries (mean = 9.260) than non-beneficiaries. Level of production of maize $(t=3.165$, $p<0.05)$ cassava $(t=3.679, p<0.05)$ and fish $(t=1.869, p<0.05)$ was also higher for beneficiaries. Beneficiaries attained higher level of production for cassava, maize and fish production than nonbeneficiaries. Efforts should be made to improve on the coverage of similar projects in the future.

Keywords: Beneficiaries, Fadama, Extension services, Privatisation 
Creative commons User License: CC BY-NC-ND

Abstracted by: EBSCOhost, Electronic Journals Service (EJS), Google Scholar, Directory of Open Access Journals (DOAJ), Journal Seek, Scientific Commons,

Food and Agricultural Organization (FAO), CABI and Scopus
Journal of Agricultural Extension

Vol. 21 (3) October, 2017

ISSN(e): 24086851; ISSN(Print); 1119944X

http://journal.aesonnigeria.org

http://www.ajol.info/index.php/iae

Email: editorinchief@aesonnigeria.org

\section{Introduction}

Nigeria's agricultural policy seeks to attain self-sustaining growth in all the subsectors of agriculture as well as realise the structural transformation relevant for overall socio-economic development of rural areas (FMARD, 1988, 2000). The strategy for achieving the objective emphasises the importance of agricultural extension to the goal attainment of the agricultural sector. In addition, Nigeria's Agricultural Transformation Agenda launched in 2012 articulated an Agricultural Extension Transformation to effectively achieve the National and household food security, improved rural livelihoods and indeed, make Nigeria's agriculture competitive in the world agricultural market. However, the present Nigerian extension system, characterized by public extension service executed by Ministries of Agriculture and Agricultural Development Programmes (ADPs) is faced with several problems which have been identified to include: lack of a legislated agricultural extension policy, frequent change in policy; grossly inadequate and untimely funding; poorly motivated extension staff; high level of engagement of extension staff in non-extension duties; low private sector participation; weak Research-Extension-Farmer-Inputs Linkage System(REFILS); driven by ineffective top-down, supply-driven, extension approaches; and a general absence of accountability in the public sector(Agbamu,2011 and Adejo et al, 2011). Apart from the above factors that render public extension service delivery which is supply driven ineffective, Nigerian farmers have poor access to extension services due to poor public relation of extension workers, illiteracy, poor radio and television signals in rural areas, lack of fund to purchase newsletters, leaflets, community news papers and bad feeder roads which make farm visits by extension workers difficult (Arokoyo, 2005). Extension is principally funded by government in the country and efforts are being made to test run its privatization.

Privatization of advisory services in Fadama 111 Project was expected to disseminate agricultural information that were based on farmers' felt needs and incorporate effective feedback from farmers. Privatization is to enhance efficiency and effectiveness of delivery of advisory services to farmers by providing timely and appropriate extension services based on farmers needs. Demand-driven extension encourages competition among providers of advisory services. In summary, privatization of advisory services in Fadama III Project was expected to enhance farmers' productivity and assist to ensure a guaranteed market for their produce. Notwithstanding the above high expectation, privatization of advisory services in Fadama III might face some challenges including farmers' unwillingness to pay for advisory services, lack of professionalism, incompetence of extension workers and inadequate infrastructures.

Fadama III Project was a national project which was a follow up to the Fadama II Project which was implemented in 18 Nigerian States (with World Bank support in 12 States and the African Development Bank (ADB) in 6 States). The project was a development intervention jointly financed by the world bank $(55.6 \%)$ and the Federal, State and Local Governments in the ratio of $5.1 \%, 17.1 \%$ and $8.9 \%$ respectively while the participating communities were expected to contribute $11.3 \%$. Fadama III was implemented from 2009 to 2013 in Oyo State 
Creative commons User License: CC BY-NC-ND

Abstracted by: EBSCOhost, Electronic Journals Service (EJS), Google Scholar, Directory of Open Access Journals (DOAJ), Journal Seek, Scientific Commons,

Food and Agricultural Organization (FAO), CABI and Scopus
Journal of Agricultural Extension

Vol. 21 (3) October, 2017

ISSN(e): 24086851; ISSN(Print); 1119944X

http://journal.aesonnigeria.org

http://www.ajol.info/index.php/jae

Email: editorinchief@aesonnigeria.org

The Project Development Objective was to increase the income of users of rural land and water resources on a sustainable basis and to build the capacity of the rural dwellers including the vulnerable groups (women and youth). This was to be achieved by directly delivering resources to the beneficiary rural communities and empowering them to collectively decide on how resources were allocated and managed for their livelihood activities and to participate in the design and execution of their subprojects. In addition, a team of facilitators were deployed in each community to provide training and technical assistance support to ensure that Fadama resource users, including women and other vulnerable groups had a voice in the decision-making process and benefitted equitably from project resources. This they did by developing the Local Development Plan (LDP) for their communities.

The need to significantly enhance productivity and income among the predominantly poor farm households was the driving force for implementation of the National Fadama Development Project (NFDP) in Nigeria. The third phase of the project popularly known as Fadama III was implemented to support the government's strategic objective of enhancing growth in the non-oil sectors in order to achieve increased food security, reduce poverty as well as create employment and improved opportunities in rural areas. The design was that the project would ride on the vehicle of improved technologies to deliver the project expectations. Hence, the project invested heavily on dissemination of improved technologies through the project's support for provision of advisory services by private service providers, capacity building through training/ seminars, input support and productive assets acquisition as well as project's support to the ADPs' sponsored research and on-farm demonstration to aid extension service delivery.

The weaknesses and inefficiencies associated with the public extension system have led to increased agitation for greater participation of the private sector in agricultural extension delivery (Matanmi et. al., 2008; Saliu and Ige, 2009; Agbamu and Okagbare, 2009). Ajieh et al, (2008) studied the constraints to privatization and commercialization of agricultural extension services, Adejo et. al, (2012) examined the challenges and prospects of privatization of agricultural extension service delivery in Nigeria. Ngwu (2004) also investigated reaction of farmers to privatization and commercialization of agricultural extension services in Ebonyi State Agricultural Development Programme, and elsewhere, Farhad and Seyyed, (2011) assessed factors influencing privatization of agricultural extension in Iran. The design of the advisory service component of Fadama III followed a modified form of public-private agricultural extension delivery approach which involved a demand driven approach for provision of advisory services. Under Fadama III project, agricultural advisory services were rendered by both private and public service providers and the project financed advisory services demanded by beneficiary farmers. Therefore, Fadama III project offers a good platform for analysing the implications of privatization of agricultural advisory services in Nigeria. Previous studies on the privatization and commercialization of agricultural advisory services have scanty data on the implication of privatized agricultural advisory services on Fadama project beneficiaries' production. Hence, this study was conceptualized to fill the gap by providing answers to the following research questions.

i. What are the personal characteristics of Fadama III beneficiaries and nonbeneficiaries? 
Creative commons User License: CC BY-NC-ND

Abstracted by: EBSCOhost, Electronic Journals Service (EJS),

Google Scholar, Directory of Open Access Journals (DOAJ),

Journal Seek, Scientific Commons,

Food and Agricultural Organization (FAO), CABI and Scopus
Journal of Agricultural Extension

Vol. 21 (3) October, 2017

ISSN(e): 24086851; ISSN(Print); 1119944X

http://journal.aesonnigeria.org

http://www.ajol.info/index.php/iae

Email: editorinchief@aesonnigeria.org

ii. What is the level of access of Fadama III beneficiaries and non-beneficiaries to advisory services?

iii. What is the level of production of Fadama III beneficiaries and nonbeneficiaries?

\section{Methodology}

This study was conducted in Oyo State which covers approximately an area of 28,454 square kilometers and is ranked $14^{\text {th }}$ by size among the 36 States in Nigeria. The climate is equatorial, notably with dry and wet seasons with relatively high humidity. The dry season lasts from November to March while the wet season starts from April and ends in October. Average daily temperature ranges between $25^{\circ} \mathrm{C}$ $\left(77.0^{\circ} \mathrm{F}\right)$ and $35^{\circ} \mathrm{C}\left(95.0^{\circ} \mathrm{F}\right)$, almost throughout the year. Agriculture is the main occupation of the people of Oyo State. The climate in the State favours the cultivation of crops like maize, yam, cassava, millet, rice, plantains, citrus, cocoa, oil palm, cashew etc. The State has thirty-three Local Government Areas (LGAs), 5 of them are in the municipal. Fadama III Project was implemented in twenty LGAs covering the three Senatorial Districts of the State.

The target population of study was all Fadama III project beneficiaries and nonbeneficiaries in Oyo State who were involved in the production of maize, cassava, poultry and fisheries. These were the major agricultural activities promoted by Fadama III project in the study area.

Multi-stage sampling procedure was adopted in the sampling process. The first stage was the stratification of the State into two, which include Fadama III participating LGAs and non-Fadama III participating LGAs. The second stage was the selection of four Local Government Areas (2 from Fadama and 2 from non-Fadama LGAs) out of the 33 LGAs of Oyo State. The third stage was the selection of four villages/communities in each of the selected LGAs for data collection. The fourth stage of the sampling was the proportionate selection of 150 Fadama III beneficiaries from Fadama Users Groups (FUGs) and 150 non-beneficiaries from ADP farmers in the selected villages thus giving a total of 300 respondents.

Farmers' production on maize, cassava, poultry and fish were measured in interval level. Total score as well as mean score for Fadama III beneficiaries and nonbeneficiaries were calculated for each of the farming enterprises. The mean score was used to categorize beneficiaries and non-beneficiaries into high or low level of production. Respondents whose scores were equal to or above mean score were classified as high level of production and below the mean score as low level. Access to advisory services was measured at ordinal level using 3-point scale of 2, 1 and 0 , assigned to full access, partial access and no access respectively. Respondents were requested to indicate their level of access to 6 different advisory services. Thus the maximum score under access to advisory services is 12 , minimum is 0 . Mean score was used to categorise Fadama beneficiary as well as non-beneficiary into high or low level of access. As for personal characteristics, age and farming experience of respondents were measured in years (interval scale), sex at nominal scale and education at ordinal scale (highest education level attained by each respondent). Descriptive statistics such as frequency, percentage, means and 
Creative commons User License: CC BY-NC-ND

Abstracted by: EBSCOhost, Electronic Journals Service (EJS),

Google Scholar, Directory of Open Access Journals (DOAJ),

Journal Seek, Scientific Commons,

Food and Agricultural Organization (FAO), CABI and Scopus
Journal of Agricultural Extension

Vol. 21 (3) October, 2017

ISSN(e): 24086851; ISSN(Print); $1119944 X$

http://journal.aesonnigeria.org

http://www.ajol.info/index.php/jae

Email: editorinchief@aesonnigeria.org

standard deviation and inferential statistics such as Chi-square, Pearson Product Moment Correlation and T-test were used to analyse the data collected.

\section{Results and Discussion}

\section{Socio-economic Characteristics of Respondents}

The study revealed that both male $(76.4 \%)$ and female $(23.6 \%)$ were involved in Fadama III project while the corresponding values for Non- Fadama farmers were 93.3\% male and $6.7 \%$ female (Table I). This shows that there were more women Fadama farmers than women non-beneficiaries. This could be attributed to the Community Driven Development (CDD) approach adopted by Fadama project which assisted in the deliberate inclusion of women farmers in the project design and implementation. Most $(52.7 \%)$ of the beneficiaries had tertiary education, while $(33.6 \%)$ of the non-beneficiaries possessed secondary education. This suggests that Fadama beneficiaries were more educated than the non-beneficiaries. The implication of this finding is that literacy was not a constraint in Fadama II project. Most $(60.3 \%)$ of Fadama beneficiaries and majority $(52.1 \%)$ of non-beneficiaries were in the age bracket of 31-50 years. The mean age for beneficiaries and nonbeneficiaries were 48.32 and 49.68 years respectively. This implies that farmers in the study area were in the middle age category. This finding corroborates Ekong (2003) assertion that Nigerian farmers are in the middle age bracket. Table 1 also shows that most $(74.7 \%)$ of beneficiaries had access to credit, compared to nonbeneficiaries $(25.0 \%)$. This implies that Fadama beneficiaries had better access to credit facilities than non-beneficiaries. The study reveals that the major sources of credit to Fadama farmers were Fadama User Groups (52.8\%), commercial bank $(43.8 \%)$ and local money lender (38.9\%), whereas for non-beneficiaries the major sources were commercial bank (53.4\%), local money lender (47.3\%) and Esusu group (43.8\%). The study reveals that many Fadama beneficiaries and nonbeneficiaries access credit through commercial banks with high interest rate which adversely affects overall returns on investment and discourages farmers from obtaining loan to expand their farming activities. These findings on access and sources of credit agree with the assertion of Akangbe et.al, $(2012,2013)$ who reported that Fadama farmers had better access to credit facilities than nonbeneficiaries and that Fadama farmers obtained their credit mostly from Fadama User Groups. 
Creative commons User License: CC BY-NC-ND

Abstracted by: EBSCOhost, Electronic Journals Service (EJS),

Google Scholar, Directory of Open Access Journals (DOAJ),

Journal Seek, Scientific Commons,

Food and Agricultural Organization (FAO), CABI and Scopus
Journal of Agricultural Extension

Vol. 21 (3) October, 2017

ISSN(e): 24086851; ISSN(Print); 1119944X

http://journal.aesonnigeria.org

http://www.ajol.info/index.php/iae

Email: editorinchief@aesonnigeria.org

Table 1: Percentage distribution of respondents according to selected socioeconomic characteristics

\begin{tabular}{|c|c|c|}
\hline Variable & $\begin{array}{l}\text { Beneficiaries } \\
(n=146)\end{array}$ & $\begin{array}{l}\text { Non beneficiaries } \\
(n=144)\end{array}$ \\
\hline \multicolumn{3}{|l|}{ Age } \\
\hline$\leq 30$ & 8.2 & 2.8 \\
\hline $31-40$ & 21.3 & 19.5 \\
\hline $41-50$ & 39.0 & 32.6 \\
\hline $51-60$ & 17.8 & 21.5 \\
\hline $61-70$ & 13.7 & 14.6 \\
\hline$>70$ & 0 & 9.0 \\
\hline \multicolumn{3}{|l|}{ Sex } \\
\hline Male & 76.4 & 93.3 \\
\hline Female & 23.6 & 6.7 \\
\hline \multicolumn{3}{|l|}{ Education } \\
\hline Tertiary & 52.7 & 12.1 \\
\hline Secondary & 31.5 & 33.6 \\
\hline \multicolumn{3}{|l|}{ Farming experience } \\
\hline $1-10$ years & 40.6 & 34.7 \\
\hline $21-30$ years & 18.3 & 31.0 \\
\hline \multirow{2}{*}{\multicolumn{3}{|c|}{ Sources of credit }} \\
\hline & & \\
\hline Local money lender & 38.9 & 47.3 \\
\hline Esusu group & 36.1 & 43.8 \\
\hline Commercial bank & 43.8 & 53.4 \\
\hline Fadama users group & 52.8 & 0 \\
\hline $\begin{array}{l}\text { Government Agricultural Credit } \\
\text { Agencies }\end{array}$ & 21.2 & 16.7 \\
\hline
\end{tabular}

Source: Field survey, 2014

Respondents' Sources of Information on Advisory Services

Table 2 shows that most of the Fadama III beneficiaries obtained information on advisory services from friends (91.0\%), extension agents $(89.6 \%)$ and radio $(85.4 \%)$ while most of the non-beneficiaries obtained their information from extension agents $(97.9 \%)$, radio $(95.2 \%)$ and group meetings $(81.5 \%)$. The study revealed that extension agents and radio were major sources of disseminating agricultural information in the study area, both for beneficiaries and non-beneficiaries. This finding is in agreement with that of Olaleye et.al (2009) who reported that most farmers in Nigeria obtain agricultural information through radio and extension agents. 
Creative commons User License: CC BY-NC-ND

Abstracted by: EBSCOhost, Electronic Journals Service (EJS),

Google Scholar, Directory of Open Access Journals (DOAJ),

Journal Seek, Scientific Commons,

Food and Agricultural Organization (FAO), CABI and Scopus
Journal of Agricultural Extension

Vol. 21 (3) October, 2017

ISSN(e): 24086851; ISSN(Print); 1119944X

http://journal.aesonnigeria.org

http://www.ajol.info/index.php/jae

Email: editorinchief@aesonnigeria.org

Table 2: Sources of information on advisory services

\begin{tabular}{lllll}
\hline Source of information & $\begin{array}{l}\text { Beneficiaries } \\
(\mathbf{n = 1 4 6 )}\end{array}$ & Rank & $\begin{array}{l}\text { Non- } \\
\text { beneficiaries } \\
(\mathbf{n = 1 4 4 )}\end{array}$ & Rank \\
\hline Extension agent & 89.6 & $2^{\text {nd }}$ & 97.9 & $1^{\text {st }}$ \\
Printed materials & 51.4 & $6^{\text {th }}$ & 13.7 & $8^{\text {th }}$ \\
Group meetings & 69.4 & $4^{\text {th }}$ & 81.5 & $3^{\text {rd }}$ \\
Agric show & 47.2 & $8^{\text {th }}$ & 75.3 & $4^{\text {th }}$ \\
Radio & 85.4 & $3^{\text {rd }}$ & 95.2 & $2^{\text {nd }}$ \\
Drama & 6.9 & $10^{\text {th }}$ & 2.1 & $10^{\text {th }}$ \\
Mobile phone & 53.5 & $5^{\text {th }}$ & 3.4 & $9^{\text {th }}$ \\
Friends & 91.0 & $1^{\text {st }}$ & 74.7 & $5^{\text {th }}$ \\
Television & 48.6 & $7^{\text {th }}$ & 19.2 & $6^{\text {th }}$ \\
Mobile cinema & 1.4 & $11^{\text {th }}$ & 0 & $11^{\text {th }}$ \\
Text message & 22.2 & $9^{\text {th }}$ & 18.5 & $7^{\text {th }}$ \\
\hline
\end{tabular}

Source: Field survey, 2014

\section{Respondents' Access to Advisory Services}

Table 3 shows that farm input (mean $=1.62$ ), improved farming practices (mean $=$ 1.52 ) as well as storage and local processing (mean $=1.47$ ) were the major advisory services accessible to the beneficiaries. The table further reveals that Fadama III beneficiaries had higher level of access to advisory services than the nonbeneficiaries for all the various advisory services covered in the study. This is expected to translate into improved productivity among beneficiaries than the nonbeneficiaries in the study area.

Table 3: Percentage distribution of respondents based on access to advisory services

\begin{tabular}{|c|c|c|c|c|c|c|c|c|}
\hline \multirow[t]{2}{*}{ Advisory services } & \multicolumn{4}{|c|}{$\begin{array}{l}\text { Beneficiaries } \\
(n=146)\end{array}$} & \multicolumn{4}{|c|}{$\begin{array}{l}\text { Non-beneficiaries } \\
(n=144)\end{array}$} \\
\hline & $\begin{array}{l}\text { No } \\
\text { access }\end{array}$ & $\begin{array}{l}\text { Partial } \\
\text { access }\end{array}$ & $\begin{array}{l}\text { Full } \\
\text { access }\end{array}$ & Mean & $\begin{array}{l}\text { No } \\
\text { access }\end{array}$ & $\begin{array}{l}\text { Partial } \\
\text { access }\end{array}$ & $\begin{array}{l}\text { Full } \\
\text { access }\end{array}$ & Mean \\
\hline $\begin{array}{l}\text { Improved farming } \\
\text { practices }\end{array}$ & 5.6 & 36.8 & 57.6 & 1.52 & 3.4 & 72.6 & 24.0 & 0.53 \\
\hline $\begin{array}{l}\text { Storage and local } \\
\text { processing }\end{array}$ & 3.5 & 45.8 & 50.7 & 1.47 & 4.8 & 37.0 & 50.7 & 0.59 \\
\hline Farm input supply & 4.2 & 29.2 & 66.7 & 1.62 & 0 & 30.8 & 69.2 & 0.46 \\
\hline $\begin{array}{l}\text { Marketing of farm } \\
\text { produce }\end{array}$ & 2.8 & 48.6 & 48.6 & 1.45 & 2.1 & 37.0 & 61.0 & 0.53 \\
\hline $\begin{array}{l}\text { Social/cultural } \\
\text { information }\end{array}$ & 4.2 & 50.7 & 45.1 & 1.41 & 8.2 & 39.7 & 52.1 & 0.64 \\
\hline Legal information & 13.9 & 49.3 & 36.8 & 1.22 & 21.2 & 26.0 & 52.7 & 0.80 \\
\hline
\end{tabular}

Source: Field survey, 2014

\section{Level of Production of Agricultural Commodities among Beneficiaries and Non-Beneficiaries}

Table 4 shows that most of the beneficiaries recorded higher level of production compared to non-beneficiaries. The table further shows that an average yield of 7 
Creative commons User License: CC BY-NC-ND

Abstracted by: EBSCOhost, Electronic Journals Service (EJS), Google Scholar, Directory of Open Access Journals (DOAJ), Journal Seek, Scientific Commons,

Food and Agricultural Organization (FAO), CABI and Scopus
Journal of Agricultural Extension

Vol. 21 (3) October, 2017

ISSN(e): 24086851; ISSN(Print); 1119944X

http://journal.aesonnigeria.org

http://www.ajol.info/index.php/jae

Email: editorinchief@aesonnigeria.org

tons of maize was reported by the beneficiaries as against an average of 3.44 tons by non-beneficiaries. Also, an average of 61.8 tons of cassava was recorded by Fadama III beneficiaries as against 37.9 tons for non-beneficiaries. Result from the study further shows that Fadama III farmers produced an average of 810 poultry birds as against 553 for non -beneficiaries. An average of 6,489 crates of eggs was equally produced by the beneficiaries while the non-beneficiaries produced an average of 5,391 crates. Table 4 further shows that farmers who participated in Fadama III project produced an average of $2,841 \mathrm{~kg}$ of fish compared to the nonbeneficiaries with an average of $1,924 \mathrm{~kg}$. This implies that Fadama III has increased the level of productivity of its farmers far above non-beneficiaries in the study area. This development can be attributed to the higher level of access to advisory services which Fadama III beneficiaries had over non-beneficiaries. The result is in consonance with Nwachukwu, Agwu, Eze, Mbanaso, Onyenweaku and Kamulu (2008) who identified Fadama project as a recent effort of the government towards boosting production and enhancing farmers' welfare.

Table 4: Distribution of beneficiaries and non-beneficiaries based on level of production across different enterprise categories

\begin{tabular}{|c|c|c|c|c|}
\hline \multirow{2}{*}{ Production } & \multicolumn{2}{|c|}{$\begin{array}{l}\text { Beneficiaries } \\
(n=146)\end{array}$} & \multicolumn{2}{|c|}{$\begin{array}{l}\text { Non beneficiaries } \\
(n=144)\end{array}$} \\
\hline & Mean & SD & Mean & SD \\
\hline $\begin{array}{l}\text { Maize production ( in } \\
\text { tons) }\end{array}$ & 7.48 & 13.22 & 3.44 & 6.72 \\
\hline $\begin{array}{l}\text { Cassava production( in } \\
\text { tons) }\end{array}$ & 61.77 & 68.15 & 36.85 & 37.94 \\
\hline No of poultry birds & 809.89 & 553.14 & 553.14 & 596.65 \\
\hline No of crates of eggs & 6489.74 & 5391.53 & 5922.2 & 6613.81 \\
\hline Fish harvested (in kg) & 2840.88 & 3307.16 & 1507.40 & 1923.56 \\
\hline
\end{tabular}

Source: Field survey, 2014

\section{Difference in the Level of Agricultural Production of Fadama III Beneficiaries and Non-Beneficiaries}

Table 5 shows that there is significant difference between Fadama beneficiaries and non-beneficiaries in their level of maize $(t=3.165)$ and cassava ( $t=3.679)$ production, as the mean level of production for beneficiaries (maize: 7.48 tons, cassava: 61.76 tons) was significantly higher than for non-beneficiaries (maize: 3.43 tons, cassava: 36.84 tons). This can be traceable to lower access to advisory services by nonbeneficiaries as reported earlier in this study. This implies that with access to advisory services by farmers, food production will increase and hunger will reduce among rural dwellers. The finding agrees with Ezeokeke, Anyanwu and Okoro (2012) who posited that Fadama project recorded success in achieving greater food production, employment generation and poverty reduction among beneficiaries. However, for the three livestock enterprises considered in this study, only fish production showed significant difference between beneficiaries and non-beneficiaries in their level of production ( $\mathrm{t}=1.869$, mean for beneficiaries $=2840.9 \mathrm{~kg}$ and mean for non-beneficiaries $=1507.4 \mathrm{~kg}$ ). This finding may be an indication that support services provided by Fadama III project favoured production of fish more than other 
Creative commons User License: CC BY-NC-ND

Abstracted by: EBSCOhost, Electronic Journals Service (EJS),

Google Scholar, Directory of Open Access Journals (DOAJ),

Journal Seek, Scientific Commons,

Food and Agricultural Organization (FAO), CABI and Scopus
Journal of Agricultural Extension

Vol. 21 (3) October, 2017

ISSN(e): 24086851; ISSN(Print); 1119944X

http://journal.aesonnigeria.org

http://www.ajol.info/index.php/jae

Email: editorinchief@aesonnigeria.org

types of livestock considered in this study. After all, access to advisory services in Fadama III project may not have addressed the felt needs of beneficiaries in different enterprises in the agricultural sector.

Table 5: Difference between the level of agricultural production (across different enterprises) of Fadama III beneficiaries and non-beneficiaries in the study area

\begin{tabular}{lllll}
\hline Groups & Mean & SD & Df & t \\
\hline $\begin{array}{l}\text { Maize } \\
\text { Beneficiaries }\end{array}$ & 7.48 & 13.22 & 252 & $3.165^{*}$ \\
$\begin{array}{l}\text { Non-beneficiaries } \\
\text { Cassava }\end{array}$ & 3.43 & 6.71 & & \\
$\begin{array}{l}\text { Beneficiaries } \\
\text { Non-beneficiaries }\end{array}$ & 61.76 & 68.14 & 249 & $3.679^{*}$ \\
$\begin{array}{l}\text { Poultry (Meat) } \\
\text { Beneficiaries }\end{array}$ & 809.89 & 37.94 & & \\
$\begin{array}{l}\text { Non-beneficiaries } \\
\text { Poultry (Egg) }\end{array}$ & 553.13 & 596.65 & & \\
$\begin{array}{l}\text { Beneficiaries } \\
\text { Non-beneficiaries }\end{array}$ & 6489.74 & 5391.52 & & \\
$\begin{array}{l}\text { Fish } \\
\text { Beneficiaries }\end{array}$ & 2840.80 & 6613.80 & & \\
$\quad$ Non-beneficiaries & 1507.40 & 1923.56 & & \\
\hline
\end{tabular}

${ }^{\star} \mathrm{P} \leq 0.05$. Source: Field survey, 2014

\section{Conclusion and Recommendation}

There is no discrimination between male and female in the process of implementing Fadama III project as both male and female gender was involved. There were more educated farmers among Fadama III beneficiaries than their non-beneficiary counterparts. Fadama III served as a good platform for sourcing advisory services on farm enterprises. Fadama beneficiaries achieved higher level of access to advisory services than non-beneficiaries. This is expected to positively influence beneficiaries' production. Significantly higher level of production was achieved among beneficiaries for cassava, maize and fish production, implying that privatized advisory services provided by Fadama III project impacted positively on beneficiaries by improving their productivity significantly. However, level of production of poultry meat and eggs was not significantly different between beneficiaries and nonbeneficiaries. It implies that the impact of Fadama III has not been all encompassing. The study recommends that privatized advisory services should be adopted by the government and future intervention projects should avoid elite capture to ensure equitable participation of both educated and illiterate farmers. Secondly, next phase of Fadama project should focus evenly on all major agricultural enterprises for the development of all sectors of agriculture. 
Creative commons User License: CC BY-NC-ND

Abstracted by: EBSCOhost, Electronic Journals Service (EJS),

Google Scholar, Directory of Open Access Journals (DOAJ),

Journal Seek, Scientific Commons,

Food and Agricultural Organization (FAO), CABI and Scopus
Journal of Agricultural Extension

Vol. 21 (3) October, 2017

ISSN(e): 24086851; ISSN(Print); 1119944X

http://journal.aesonnigeria.org

http://www.ajol.info/index.php/iae

Email: editorinchief@aesonnigeria.org

\section{References}

Adejo, P.E., Okwu, O.J. and Ibrahim, M.K. (2012): Challenges and Prospects of Privatization of Agricultural Extension Services Delivery in Nigeria. Journal of Agricultural Extension and Rural Development, 4(3): 63-68.

Agbamu, J.U., Okagbare, G.O. (2005): Institutional Strengthening of Ogun State ADP upon Expiration of World Bank Assistance. In A.M. Orheruata, S.O. Nwokoro, M.T, Ajayi,A.T, Adekunle and Asumugha, G.N. (eds), Agricultural Rebirth for Improved Production in Nigeria. Proceedings of the $39^{\text {th }}$ Annual Conference of the Agricultural Society of Nigeria, held at the University of Benin, Benin City, October 9-13, pp. 322-325.

Ajieh, P.C., Agwu A.E., Anyawu A.C. (2008): Constraints to Privatization and Commercialization of Agricultural Extension Services as perceived by Extension Professional and Farmers. African Journal of Agricultural Research, 3(5): 343-347.

Akangbe JA, Ogunyinka, W., Ayanda, I.F., Achem, B. And Adisa R.S (2012): An assessment of effects of Fadama II project on livelihood of farmers in Orire Local Govt Area of Oyo state. Nigerian journal of Agriculture, Food and Environment 8(1): 27-32

Arokoyo, T. (2005). ICTs application in agricultural extension service delivery. In: Adedoyin, F. S. (ed). Agricultural Extension in Nigeria. AESON, Ilorin, 246.

Ekong, E. E. (2003). Rural Sociology: An introduction and analysis of rural Nigeria, Uyo: Dove Education publication pp23-27

Ezeokeke, C. T., Anyanwu, N. J. and Okoro, V. M. O. (2012). Impact of fadama II project on feed, food and Poverty in Imo state. International Journal of Applied Sociology, 2(3): 22-24 doi: 10.5923/j.ijas.20120203.03

Federal Ministry of Agriculture and Rural Development (1988): Nigeria's Agricultural Policy, Federal Republic of Nigeria.

Federal Ministry of Agriculture and Rural Development (2000): Agriculture in Nigeria, the New Policy Thrust, Federal Republic of Nigeria.

Matanmi BM, Adesiji GB and D F. Omokore. Need for privatization of agricultural extension services in Nigeria global approaches to extension practice (GAEP). 2008;4(2):6

Ngwu G. C.(2004). Reaction of farmers to Privatization and Commercialization of Agricultural Extension Services in Ebonyi State, Nigeria. M.Sc. Thesis: Department of Agricultural Extension, University of Nigeria, Nsukka.

Nwachukwu, I.N, Agwu N.M, Ezeh C.I, Mbanasor J.A, Onyenweaku C.O, and Kamalu C.E. (2008). Evaluation of Second National Fadama Development Project in Nigeria: A rapid Policy Appraisal. http://mpra.ub.unimuenchen.de/12914/.

Saliu, O.I. and Aje, A.I.(2009). Privatisation of Agricultural Extension Services in Nigeria. Proposed Guidelines for Implementation. American Eurasian Journal of Sustainable Agriculture, 3(3): 332-339. 